\title{
Publications in the Sudan
}

THE Ministry of Education in the Sudan has published a report on the work of the two publication bureaux at Khartoum and at Juba for the period from 1952 to 1954 . Since early in 1955 the publications section of the Ministry has been working with an entirely Sudanese staff; all expatriate advisers have been replaced by Sudanese. During the last six years, fourteen members of the staff have been sent for training in the British Isles, Egypt, or in the Sudan. One of the present illustrators has recently returned from a course in commercial art in Leicester; three have had a general art course in the Art School of the Khartoum Technical Institute or the School of Design of Gordon College. One student has taken a threeyear course in typography and printing at the Camberwell School of Arts and Crafts, and a second began a similar course in I955.

The Khartoum Bureau prepares textbooks for the elementary and intermediate schools; the Institute of Education at Bakht-er-Ruda, from which the Bureau developed, writes and revises the books, and the Bureau sees to illustration, layout and typography before sending them to the printer. The Bureau does not yet print books in the large numbers that would be needed for this market: editions of some 60,000. It does, however, print its own material when small editions are needed, as in teachers' handbooks for use in intermediate schools. The problem of the small edition is more pressing at Juba, where Arabic has not yet become completely the lingua franca of the multilingual South, and much experimental work has to be done in preparing Arabic material for readers to whom it is a foreign tongue.

Both Bureaux do a great deal of work in visual aids. In Khartoum, several series of posters have been produced, one on the history of the Sudan for elementary schools, another on geography for elementary schools, others for campaigns against bilharzia and for information on local government. Juba's work has been more elementary; it has included Arabic flash cards and pictorial vocabularies.

The fortnightly youth magazine El Sibyan has been running for nine years, and ' continues in popularity despite the doubling of its price to two piastres to meet increased costs of paper and printing'. Its average sales are 13,000 copies an issue, and it has reached over 21,000. In March I954 the Bureau began publishing an Arabic monthly, El Kubaar, to provide educational and recreational matter in simple Arabic for adult readers of limited schooling. El Kubaar sells six to seven thousand copies per issue 'in spite of distribution problems'. The Juba Bureau publishes an Arabic monthly, mainly for teachers, and Future, a quarterly in English and Arabic, which serves a wider field.

The Bureaux face a difficult problem of distribution. 'Much of the vast area of a million square miles which they serve is notable for poor communications; roads in many cases are closed for two to three months of the year; there is no railroad south of the twelfth parallel or west of El Obeid, and even in the dry season parcels may be two to three weeks in transit to outlying places.' An encouraging experiment has been made with travelling bookshops. At the beginning of I95s the Khartoum Bureau made a new experiment. 'A merchant is being nominated to serve as an agent for the supply of books and magazines. These merchants also agree to carry a small stock for sale to the general public. Although some small village schools will have to be served direct it is hoped that this move towards more normal commercial practice will provide much wider book-buying facilities for both adults and children' (Oversea Education, July 1956).

\section{Training for Social Welfare and Community Development}

ThE Department of Social Welfare and Community Development in the Gold Coast produces a quarterly publication called Advance. The issue for April 1956 was devoted to the question of training for community development work, and included an article by the 